\title{
Immobilization of dimethylamine and aniline using soft lignocelluloses material (abelia chinensis sawdust) for controlling striga hermonthica in sorghum field
}

\author{
Rindap Timnan Lazwan ${ }^{1 *}$, Daben Janet Moses ${ }^{2}$, Angbalaga Rechit Alexander ${ }^{3}$, Dashak Dayil Albert ${ }^{1}$ \\ ${ }^{1}$ Department of Chemistry, Faculty of Natural Sciences, University of Jos, P M B. 2084, Jos, Plateau State, Nigeria \\ ${ }^{2}$ Department of Science Laboratory Technology, Faculty of Natural Sciences, University of Jos, P M B. 2084, Jos, \\ Plateau, State, Nigeria \\ ${ }^{3}$ Department of Chemistry, College of Education Akwanga, PMB 05 Akwanga, Nassarawa State, Nigeria \\ *Corresponding author E-mail: rindaptimnan@gmail.com
}

\begin{abstract}
Chemical modifications of lignocelluloses materials are advance development that are fast and convenient to convert the low value woody residues to create channels for controlling the release of organic manure to proffer solutions to farmers in the increasing soil acidity, rapid weed's growth, soil infertility and food scarcity. The study investigates the physic-chemical parameters, and the effect of immobilized nitrogenous bases on oxidized sawdust for controlling Striga hermonthica in the sorghum field. The results indicate that the moisture content increases with increase particle size as water absorption capacity increases with time and size, thereby, ash content decrease with increase size. The control, oxidized and immobilized sawdusts were analyzed using FT-IR and it was clear that pretreated sawdust of $0.08-0.10 \mathrm{M}$ KIO4 oxidized the exposed hydroxyl groups of the lignocelluloses material to the carbonyl group but were unable in 0.04-0.06M KIO4. Likewise, the absorption bands showed that the nitrogenous bases were incorporated while carbonyl absorptions were still observed. The effect of immobilized Dimethylamine concentrations on gradual release on sorghum grows progressively with the absence of S. hermonthica while aniline grows faster than Dimethylamine at $0.5-1.0 \mathrm{M}$ then diminished at $1.5 \mathrm{M}$ than Dimethylamine. The application of immobilized amines on the sorghum field showed that this invention would enhance sorghum productivity through striga control.
\end{abstract}

Keywords: Chemical Modifications; Immobilization; Nitrogenous Bases; Sorghum and Striga Hermonthica.

\section{Introduction}

The state of developing countries farmers no longer put an interest to take farming as a carrier, business or means of livelihood. The nature of maintaining the expensive equipment's and managing scientific technologies with the available natural resources has limited the farmers in these areas. In search to curb the high rate of decreasing soil fertility, less retention of nutrients, water and constant use of farmland has increased the frequent use of inorganic fertilizers that has form complex chemical and physical changes in the soil (Lal 1998 p. 17, Azam et al. 2008 p. 56). These have helped maintained the wide spread and infestation of crops by annual hemi-parasites weed (Striga hermonthica) of monocotyledonous plants (sorghum) (Emechebe et al. 2004 p. 215, Dashak \& Shambe 2005 p. 4850 , Gurney et al. 2006 p. 199).

Striga hermonthica (giant witch weed), a parasitic plant native to Ethiopia and Sudan (Musselman 1987 p. 3 ) is known to cause substantial losses in Sorghum, Maize, Millet among the staple foods' production across Africa and South Asia ((Kamara et al. 2008 p. 349, Satish et al. 2012 p. 989). This witch weed affects up to $40 \%$ of Africa's crop production and the annual crop yield losses in West African savannas alone account for $\$ 7$ billion, affecting more than 100 million people (Emechebe et al. 2004 p. 215, Gurney et al. 2006 p. 199). S. hermonthica which quickly adapt to different hosts environments, grow well in acidic and in over-used soil (Dashak \& Shambe 2005 p. 4851) attaining up to 50\% germination under moisture regimes as a permanent wilting point for its host (Sauerborn 1994 p .249). Striga is also responsible for about $20 \%$ loss of sorghum in Africa, thus causing food scarcity experienced in African countries (Lagoke et al. 1991 p. 3).

Several striga controls have been reported of which some are: improved field-testing methodology; field inoculation with striga seeds (Haussmann et al. 2000 p. 273), susceptible and host resistant varieties (Ejeta et al. 2007 p. 216, Menkir \& Kling 2007 p.674); evaluation in specific, adjacent infested and uninfested plots (Haussmann et al. 2000 p. 273, Badu-Apraku et al. 2010 p. 262). Among others are characterization of crop germplasm and improvement of available sources of resistance; transfer and pyramiding of resistance genes into adapted, farmer-selected cultivars (Haussmann et al. 2000 p. 273, Kamara et al. 2008 p. 349). Development of string-resistant parent lines for hybrid or synthetic cultivars and random-mating populations with multiple sources of resistance genepool (Haussmann et al. 2000 p.273, Kounche et al. 2013 p.82). Though other laboratory assays are needed (Haussmann et al. 2000 p. 273) an integrated control is advised (Baduapraku 2010 p. 261). The agar-gel assay is an excellent tool to screen host genotypes in the laboratory for low production of the striga seed germination stimulant (Haussmann et al. 2000 p. 273). Inheritance of traits associated with resistance to striga spp has 
been reported for sorghum, maize and rice. Several genes are in volved in stimulation of S. hermonthica seed germination in sorghum (Haussmann et al. 2001a p. 1508, Satish et al. 2012 p. 989) and the major gene has recently been mapped (Satish et al. $2012 \mathrm{p}$. 989).

Lignocelluloses refer to plant materials, which composed of carbohydrate polymers such as cellulose, hemicelluloses, and aromatic polymer lignin (Shambe \& Tersoo 1993 p. 130). These carbohydrate polymers contain different sugar monomers of six and five carbon sugars that are tightly bound to the lignin ( $\mathrm{Yu}$ et al 2010 p. 297, Rowell 2012 p. 44). Cellulose is an unbranched homo-polysaccharide consisting of D-glucopyranosyl units (Harborne, 1993 p. 264). Hemicelluloses on the other hand, are branched hetero-polysaccharides consisting of both hexose and pentose sugar residues, which may also carry acetyl groups. The third main component, lignin, consists of phenyl-propane units linked together by different types of inter unit linkages in which the ether bonds are the most common (Rowell, 2012-39, 43, 47). Dashak \& Shambe (2005 p. 4850) in their earlier work reported that frequent and invasive cultivation practices affect the physicchemical and biological processes like organic carbon exchangeable cations of soil. Bolien (2003 p. 379) earlier stated in his research that sawdust can be utilized for humus maintenance since it is easy to do so than the usual crop rotation that does not maintain soil humus at high level as desired.

However, alkaline peroxide oxidation pretreatment is an improver of yield (Ayeni et al. 2016 p. 33) which correlate with Dash et al. (2012 p. 2069) in their study of sawdust fibers that demonstrates regio-selective oxidation of cellulose nanowhiskers which yielded $80-90 \%$ amine derivatives. They also found a corresponding increase in carbonyl content of dialdehyde cellulose nanowhiskers and the oxidant as evidenced by FT. IR spectroscopy. Furthermore, Nassauer (2011 p. 9604) in another work carried out a reaction of succinic anhydride with wood meals from Piceaabies and found out that it is suitable for the removal of heavy metals from water.

The Immobilization of the nitrogen depends on the $\mathrm{C} / \mathrm{N}$ ratio of the plant residues and generally, plant residues entering the soil have too little nitrogen for the soil microbial population to convert all of the carbon into their cells. It is suggested that lower $\mathrm{C} / \mathrm{N}$ ratio and higher nutrient compositions is preferred (Moyin-Jesu 2007 p. 2057).

Soil $\mathrm{pH}$ is considered a master variable in soils as it controls many chemical processes that take place. It specifically affects plan nutrient availability by controlling the chemical forms of the nutrient. The optimum $\mathrm{pH}$ range for most plants is between 5.5 and 7.0 however, many plants have adapted to thrive at $\mathrm{pH}$ values outside this range (Perry 2012 p.1). The components of sawdust; cellulose, hemicellulose and lignin all consist of hydroxyl groups, thus the modifications carried out in this research are possible. This work, therefore, uses the available waste material (sawdust) to carry out some chemical modifications that will enable it addressed the problems of farmers in controlling the weed as well as to restore soil fertility. This was achieved through determining the physical properties of lignocelluloses, subjecting the lignocellulose to pretreatment to make it suitable for analysis such as oxidation of the lignocelluloses using potassium periodate to convert the hydroxyl group of the lignocelluloses to carbonyl groups (aldehydes and ketones). Treat the oxidised lignocelluloses with Dimethlylamine and Aniline to effect the immobilization on sorghum farm and to observe the extend on the crop and striga weed.

\section{Materials and methods}

\subsection{Collection and preparation of samples}

The Sawdust of Abelia chinensis (soft wood), a waste substance obtained from local saw mills in Timber Market and woodwork workshops at Katako Market, Jos, Plateau State, Nigeria. The Sawdust was screened to remove impurities while the Sandy soil sample was obtained within Shandam Local Government Area of Plateau State, Nigeria by mechanical method. The surface of the soil was scrapped off, and the soil collected at $5-10 \mathrm{~cm}$ depth was homogenized. All samples were air dried and stored in sealed polythene bags for used in the laboratory.

\subsection{Sieving of samples}

The sawdust sample sizes were distributed by impact sieve shaker (SV003) to obtain $2.00 \mathrm{~mm}, 1.00 \mathrm{~mm}$ and $0.50 \mathrm{~mm}$ mesh sizes. The sieves were arranged in order of diminishing sieve sizes with a basin beneath it to collect particles from the last sieve. The top sieve was $3 / 4$ filled with an unweighed quantity of sawdust to allow shaking while the stopwatch was set at 10 minutes and the power knob at 5 . The machine was switched on and shook vigorously as relative to the set power and time. Each sieve size particles was collected into a label plastics bags for analysis.

\subsection{Determination of moisture content of sawdust}

About $1.00 \mathrm{~g}$ of each sample size in triplicate was weighed into a labeled crucible and oven dried at $105^{\circ} \mathrm{C}$ for $24 \mathrm{hrs}$, after which was allowed to cool in a dessicator for about 30mins. The loss in weight was expressed as percentage moisture content.

\subsection{Water absorption capacity of sawdust}

Mean values of $1.0 \mathrm{~g}$ of each mesh size was transferred into a $200 \mathrm{ml}$ beaker of $100 \mathrm{ml}$ distilled water which was allowed for different lengths of time ( 1 to 36 hours) at room temperature. The weight gained of samples after vacuum filtration was expressed as percentage water absorption capacity thus;

$\mathrm{Ac} \%=\frac{\mathrm{Mc}-\mathrm{Md}}{\mathrm{Md}} \times 100 \%$

$\mathrm{Ac}=$ Absorption capacity

$\mathrm{Mc}=$ Weight of sample after vacuum filtration

$\mathrm{Md}=$ Weight of dry sample.

\subsection{Determination of ash content of sample}

One gram $(1.0 \mathrm{~g})$ of moisture free samples in triplicate were transferred into a weighed porcelain crucible and placed in a muffle furnace maintained at $600^{\circ} \mathrm{C}$ for 8 hours. The weight after cooling the ash was expressed as percentage ash content.

\subsection{Oxidation of the sample}

Pulverized samples of about $1.0 \mathrm{~g}$ were treated with various concentrations of potassium periodate $\left(0.04-0.1 \mathrm{Moldm}^{-3}\right)$ and allow for 48 hours at $32^{\circ} \mathrm{C}$. The samples were filtered, washed severally with distilled water and dry in the oven at $32^{\circ} \mathrm{C}$ for 24 hours. The oxidized sawdust was used for infrared analysis to study the extend of Oxidation.

\subsection{Immobilization of nitrogenous bases on oxidized samples}

In order to incorporated dimethylamine and aniline on the oxidized sawdust, about $1.0 \mathrm{~g}$ of the oxidized sawdust was soaked in $100 \mathrm{ml}$ each of $0.5-1.5$ moldm $^{-3}$ concentrations of dimethylamine and aniline. It was then filtered using vacuum filtration after several wash with distilled water and oven dry at $32^{\circ} \mathrm{C}$ for 24 hours. Infrared analysis was run to study the extend of reaction of the amines into the oxidized sawdust.

\subsection{Determination of soil sample $\mathrm{pH}$}

Air dried soil sample size weighing $10 \mathrm{~g}$ was mixed with $10 \mathrm{ml}$ of distilled water for 10 minutes and allowed to stand for 30 minutes. 
The $\mathrm{pH}$ meter was standardized using $\mathrm{pH}$ buffer 7 and 9 and readings were taken after 30 seconds.

\subsection{Planting of sorghum seedlings and Immobilization on soil}

Perforated plastic buckets were filled with the sandy soil sample to about two - third of the bucket. S. hermonthica seeds were spread on the soil, mixed, wet with water and allow some time to enable the water percolate. It was followed by Sorghum seeds planting and after three weeks of germination, and subsequently two weeks, the immobilized sawdust was applied based on the concentrations and all labeled. The control was also observed.

\subsection{Fourier transform infrared (FT-IR)}

Infrared spectra of un-oxidized, oxidized and immobilization sawdusts were measured with a Fourier transformed infrared spectrophotometer (FT - IR P800s) to elucidate the functional group present in the sawdust. Measuring IR spectra, $5 \mathrm{mg}$ of powdered unoxidized, oxidized and immobilized nitrogenous bases sawdusts of various concentrations were encapsulated in $400 \mathrm{mg}$ of $\mathrm{KBr}$. A translucent disk was made by pressing the ground mixed material with a hydraulic press for $1 \mathrm{~min}$. The spectra were recorded in a FT- IR with the range of 500 to $4500 \mathrm{~cm}^{-1}$.

\section{Results and discussion}

\subsection{Physiochemical parameter}

The physiochemical parameters are depicted in Table 1 and figure 1. It is observed that the lignocelluloses material of Abelia chinensis moisture content (Table 1) increases with increasing particle size, as larger surface area are giving greater reactivity is a good sign for chemical modification as aimed in this research. Water absorption capacity test was also carried out as shown in figure 1 . The result confirmed that the moisture content is an evident of its capacity to retain moisture/water. For this reason, the absorption increases with time and size. This shows that the exposed hydroxyl group of the celluloses, hemicelluloses and lignin formed hydrogen bond with water, which account for the high retention of water even after centrifuging as agreed by earlier works of Clemons (2002 p. 14), Adhikary et al. (2008 p. 810).

Furthermore, the moisture content and water absorption capacity revealed that the hydroxyl group can also formed hydrogen bond with amines during immobilization. Showing that this tendencies is resulting from the ability of Nitrogen to share their pair of electrons, basicity, action of nucleophiles and in the case of aniline, unusually high reactivity due to aromatic rings bearing amino or substituted amino group (Morrison and Boyd 1997, p.845). With this, it means it can absorbed and immobilized soluble nutrients that are easily lost by leaching and run-off water and releases them with time for plant use on decomposition which continue gradually for some years. These processes help in controlling soil acidity and striga that grow mostly on acidic soil (Dashak \& Shambe 2005 p. 4851).

The result of the ash content value (Table 1) outlined that ash content decrease with increase particle size of the sawdust, a lignocellulosic material with a highest ash production from highest fines content. There is an increase burning velocity (Demirbas 2004 P. 219) which burns into carbon dioxide $\left(\mathrm{CO}_{2}\right)$ and water $\left(\mathrm{H}_{2} \mathrm{O}\right)$. Moreover, the combustion of untreated biomass is higher than their counterparts (McNamee et al. 2015 p. 63, Demirbas 2004 P. 219).

Table 1: Percentage Mean Moisture and Ash Contents

\begin{tabular}{|c|c|c|c|}
\hline Mesh Sizes & 0.5 & 1.0 & 2.0 \\
\hline$\%$ Mean Moisture Content \pm SEM & $4.13 \pm 0.04$ & $4.20 \pm 0.0$ & $4.23 \pm 0.09$ \\
\hline$\%$ mean Ash Content \pm SEM & $2.23 \pm 0.03$ & $2.21 \pm 0.0$ & $2.20 \pm 0.02$ \\
\hline
\end{tabular}

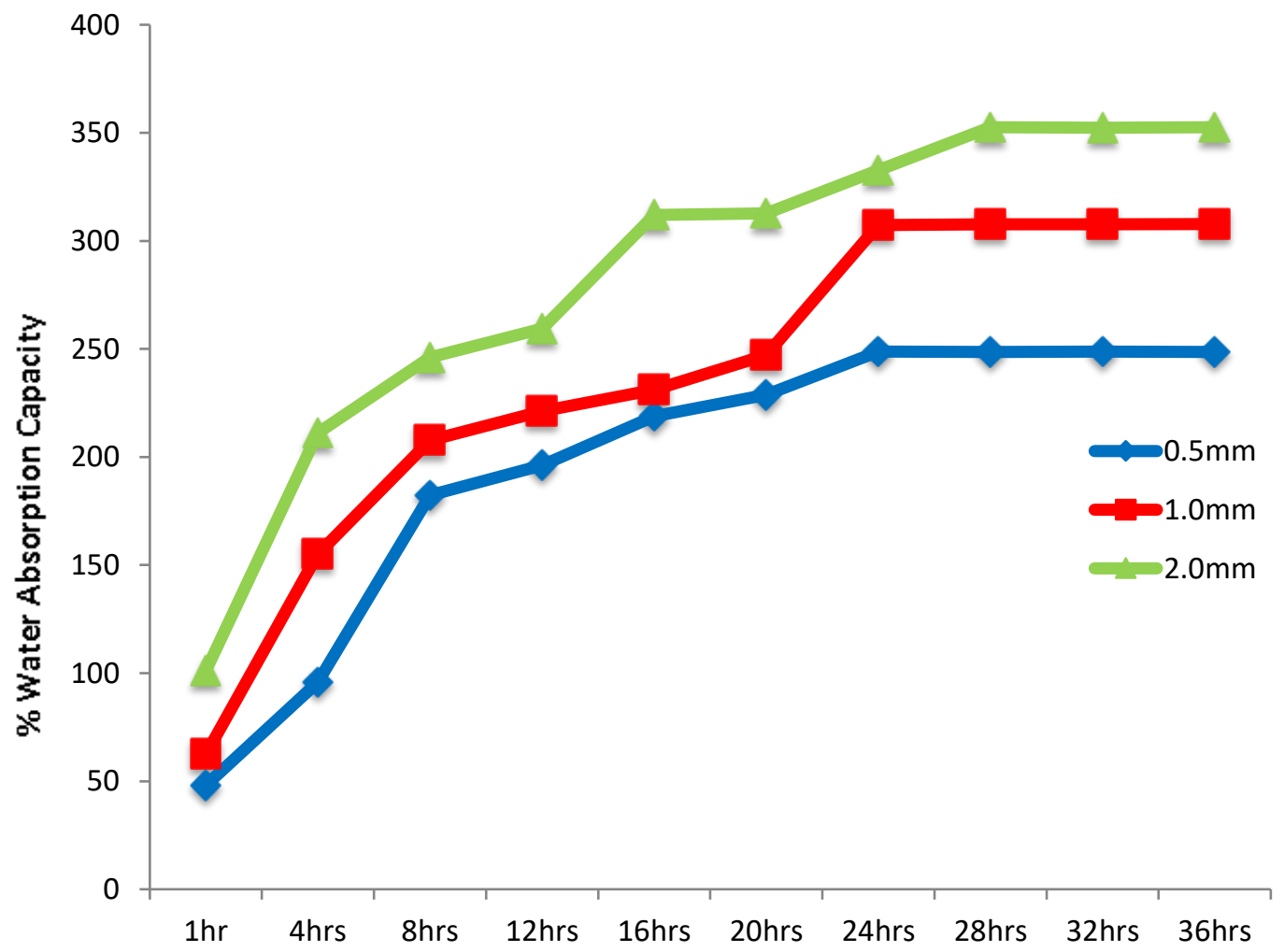

Time In Hours

Fig. 1: Percentage Water Absorption Capacity of Abelia Chinensis. 


\subsection{Infra-red results for un-oxidized and oxidized saw- dust}

Table 2: Unoxidized Sawdust (Abelia Chinensis)

\begin{tabular}{llll}
\hline S/NO & Peak $\left(\mathrm{cm}^{-1}\right)$ & Bond & Suspected Functional Group \\
\hline 1 & 3456.55 & O $-\mathrm{H}$ & Alcohol, Phenols \\
2 & 2942.51 & C $-\mathrm{H}$ & Methyl, Methylene \\
3 & 1637.62 & C $=$ C & Alkenes \\
4 & 1032.92 & C - O & Ether, alcohols \\
\hline
\end{tabular}

Table 3: $0.04 \mathrm{M} \mathrm{KIO}_{4}$ Oxidized Sawdust (Abelia Chinensis)

\begin{tabular}{|c|c|c|c|}
\hline $\mathrm{S} / \mathrm{NO}$ & Peak $\left(\mathrm{cm}^{-1}\right)$ & Bond & Suspected Functional Group \\
\hline 1 & 3448.84 & $\begin{array}{l}\mathrm{O}-\mathrm{H}, \mathrm{N} \\
-\mathrm{H}\end{array}$ & Alcohol, Amide, Amine \\
\hline 2 & 2938.65 & $\mathrm{C}-\mathrm{H}$ & Methyl, Methylene \\
\hline 3 & 1636.84 & $\mathrm{C}=\mathrm{C}$ & Alkenes \\
\hline 4 & 1437.02 & $\mathrm{C}-\mathrm{H}$ & Methyl, Methylene \\
\hline 5 & 1261.84 & $\mathrm{C}-\mathrm{H}$ & Methyl, Methylene \\
\hline 6 & 1044.49 & $\mathrm{C}-\mathrm{O}$ & Ether, Alcohols \\
\hline 7 & 557.62 & $\mathrm{C}-\mathrm{X}$ & Bromide, Iodide \\
\hline
\end{tabular}

\begin{tabular}{llll}
\hline S/NO & Peak $\left(\mathrm{cm}^{-1}\right)$ & Bond & Suspected Functional Group \\
\hline 1 & 3433.41 & $\mathrm{O}-\mathrm{H}, \mathrm{N}-\mathrm{H}$ & Alcohol, Amide, Amines \\
2 & 2940.58 & $\mathrm{C}-\mathrm{H}$ & Methyl, Methylene \\
3 & 1634.73 & $\mathrm{C}=\mathrm{O}$ & Alkenes \\
4 & 1524.74 & $\mathrm{C}=\mathrm{H}$ & Aromatics \\
5 & 1443.77 & $\mathrm{C}-\mathrm{H}$ & Methyl, Methylene \\
6 & 1250.88 & $\mathrm{C}-\mathrm{H}$ & Methyl, Methylene \\
7 & 1044.49 & $\mathrm{C}-\mathrm{O}$ & Ether, Alcohols \\
8 & 603.77 & $\mathrm{C}-\mathrm{X}$ & Bromide, Iodide \\
\hline
\end{tabular}

Table 5: 0.08 $\mathrm{M} \mathrm{KIO}_{4}$ Oxidized Sawdust (Abelia Chinensis)

\begin{tabular}{lcll} 
& Table 5: $0.08 \mathrm{M} \mathrm{KIO}_{4}$ Oxidized Sawdust (Abelia Chinensis) \\
\hline S/NO & Peak $\left(\mathrm{cm}^{-1}\right)$ & Bond & Suspected Functional Group \\
\hline 1 & 3416.05 & $\mathrm{O}-\mathrm{H}$ & Alcohols \\
2 & 2973.37 & $\mathrm{C}-\mathrm{H}$ & Methyl, Methylene \\
3 & $2903 . .93$ & $\mathrm{C}=\mathrm{H}$ & Methyl, Methylene \\
4 & 2520.05 & $\mathrm{O}=\mathrm{H}$ & Carbohydrates Acid \\
5 & 2122.73 & $\mathrm{C}=\mathrm{C}$ & Alkyne \\
6 & 1926.95 & $\mathrm{C}-\mathrm{H}$ & Aldehyde \\
7 & 1650.16 & $\mathrm{C}=\mathrm{C}$ & Alkenes \\
8 & 1387.34 & $\mathrm{C}=\mathrm{O}, \mathrm{C}-\mathrm{H}$ & Amide, Alkyls \\
9 & 1062.81 & $\mathrm{C}-\mathrm{O}$ & Ether, Alcohols \\
\hline
\end{tabular}

Table 6: $0.10 \mathrm{M} \mathrm{KIO}_{4}$ Oxidized Sawdust (Abelia Chinensis)

\begin{tabular}{llll}
\multicolumn{4}{c}{ Table 6: $0.10 \mathrm{M} \mathrm{KIO}_{4}$ Oxidized Sawdust (Abelia Chinensis) } \\
\hline S/NO & Peak $\left(\mathrm{cm}^{-1}\right)$ & Bond & $\begin{array}{l}\text { Suspected Functional } \\
\text { Group }\end{array}$ \\
\hline 1 & 3445.94 & $\mathrm{O} \mathrm{H}$ & Alcohols \\
2 & 2933.83 & $\mathrm{C}-\mathrm{H}$ & Methyl, Methylene \\
3 & $2272 . .22$ & $\mathrm{C}=\mathrm{C}$ & Alkyne \\
4 & 1732.13 & $\mathrm{C}=\mathrm{O}$ & Aldehyde \\
5 & 1640 & $\mathrm{C}=\mathrm{O}$ & Amide \\
6 & 1443.77 & $\mathrm{C}-\mathrm{H}$ & Methyl, Methylene \\
7 & 124.02 & $\mathrm{C}-\mathrm{H}$ & Methyl, Methylene \\
8 & 1039.67 & $\mathrm{C}=\mathrm{O}$ & Ether, Alcohols \\
9 & 551.66 & $\mathrm{C}-\mathrm{X}$ & Bromide, Iodide \\
\hline \multicolumn{4}{l}{ (Morrison and Boyd 1997, p. 597; Solomon and Fryhle 2007, p. 79-83). }
\end{tabular}

The infrared wavelength results for unoxidized (control) sawdust in Table 2 showed that the sample is a proper wood that contain the characteristic structure for modifications. A band at $3456.55 \mathrm{~cm}^{-1}$, is attributed to $\mathrm{O}-\mathrm{H}$ groups stretching indicating high concentration of phenols and alcohol present in carbohydrate polymers of which consists of cellulose, lignin and hemicelluloses (Clemons 2002 p. 14). The absorption at $1032.90 \mathrm{~cm}^{-1}$ for C-O-C stretching indicates ether bond linkages as characteristic structure of lignocelluloses chain. (Rowell, 2012, p. 43).

Tables' 3-6 shows the absorption bands for oxidized sawdust of $0.04-0.10 \mathrm{MKIO}_{4}$ concentrations. The absorption bands in the region $3448.84-3433.41 \mathrm{~cm}^{-1}$ of 0.04 and $0.06 \mathrm{MKIO}_{4}$ indicate high concentration of alcohol, amide and amine and stretches of ether but with absence of carbonyl compounds (Tables 3-4). Tables 5-6 of $0.08-0.10 \mathrm{MKIO}_{4}$ have high concentration of alcohol and stretch of ether, carbohydrates acid and indicate the presence of carbonyl group. These regions indicated the oxidation of the raw sawdust to an aldehyde as also reported by Dash et al. (2012 p. 2069).

\subsection{Infra-red results for modified sawdust}

Table 7: 0.5M Dimethylamine (Abelia Chinensis)

\begin{tabular}{llll} 
S/NO & Peak $\left(\mathrm{cm}^{-1}\right)$ & Bond & Suspected Functional Group \\
\hline 1 & 3374.58 & $\mathrm{~N}-\mathrm{H}$ & Amide, Amines \\
2 & 2737.68 & $\mathrm{C}-\mathrm{H}$ & Methyl, Methylene, Methine \\
3 & 2272.22 & $\mathrm{C} \Xi \mathrm{C}$ & Alkyne \\
4 & 2272.27 & $\mathrm{C} \Xi \mathrm{N}$ & Nitrite \\
5 & 1982.89 & $\mathrm{C}=\mathrm{C}$ & Aromatic \\
6 & 1851.72 & $\mathrm{C}=\mathrm{O}$ & Aldehyde, Aromatic Amides \\
7 & 1739.85 & $\mathrm{C}=\mathrm{O}$ & Ether, Alcohols \\
8 & 1618.33 & $\mathrm{C}-\mathrm{H}$ & Amines, Amide \\
9 & 1380.11 & $\mathrm{C}-\mathrm{N}$ & Amines \\
10 & 1245.09 & $\mathrm{C}-\mathrm{H}$ & Methyl, Methylene \\
11 & 1041.60 & $\mathrm{C}-\mathrm{O}$ & Ether \\
\hline
\end{tabular}

Table 8: 1.0M Dimethylamine (Abelia chinensis)

\begin{tabular}{llll}
\hline S/NO & Peak $\left(\mathrm{cm}^{-1}\right)$ & Bond & Suspected Functional Group \\
\hline 1 & 3362.04 & $\mathrm{~N}-\mathrm{H}$ & Amine, Amide \\
2 & 2922.25 & $\mathrm{C}-\mathrm{H}$ & Methyl, Methylene \\
3 & 2252.93 & $\mathrm{C} \equiv \mathrm{N} . \mathrm{N}-\mathrm{H}$ & Nitrite. Ammonium salts \\
4 & 1911.52 & $\mathrm{C}-\mathrm{H}$ & Amines, Amide \\
5 & 1724.42 & $\mathrm{C}=\mathrm{O}$ & Aldehydes \\
6 & 1652.09 & $\mathrm{~N}-\mathrm{H}$ & Amines, Amide \\
7 & 1400.37 & $\mathrm{C}-\mathrm{H}$ & Methyl, Methylene \\
8 & 1248.95 & $\mathrm{C}-\mathrm{H}$ & Methyl, Methylene \\
9 & 1043.52 & $\mathrm{C}-\mathrm{O}$ & Ether \\
\hline
\end{tabular}

Table 9: 1.5M Dimethylamine (Abelia Chinensis)

\begin{tabular}{llll}
\hline S/NO & Peak $\left(\mathrm{cm}^{-1}\right)$ & Bond & Suspected FunctionalGroup \\
\hline 1 & 3427.65 & $\mathrm{~N}-\mathrm{H}$ & Amines, Amides \\
2 & 2932.86 & $\mathrm{C}-\mathrm{H}$ & Methyl, Methylene \\
3 & 1633.86 & $\mathrm{~N}-\mathrm{H}$ & $\begin{array}{l}\text { Amines, Amides } \\
\text { Methyl, Methylene, Methine }\end{array}$ \\
4 & 1490.06 & $\mathrm{C}-\mathrm{H}$ & \\
5 & 1441.84 & $\mathrm{C}-\mathrm{H}$ & Methyl, Methylene \\
6 & 1354.07 & $\mathrm{C}-\mathrm{N}$ & Amines \\
7 & 1260.88 & $\mathrm{C}-\mathrm{H}$ & Methyl, Methylene \\
8 & 1041.60 & $\mathrm{C}-\mathrm{O}$ & Ether \\
\hline
\end{tabular}

Table 10: $0.5 \mathrm{M}$ Aniline (Abelia Chinensis)

\begin{tabular}{|c|c|c|c|}
\hline $\mathrm{S} / \mathrm{NO}$ & Peak $\left(\mathrm{cm}^{-1}\right)$ & Bond & Suspected Functional Group \\
\hline 1 & 3348.64 & $\mathrm{~N}-\mathrm{H}$ & Amines, Amides \\
\hline 2 & 2932.86 & $\mathrm{C}-\mathrm{H}$ & Methyl, Methylene \\
\hline 3 & 2256.79 & $\begin{array}{l}\mathrm{C}=\mathrm{N}, \\
\mathrm{N}-\mathrm{H}\end{array}$ & Nitrite, Ammonium salt \\
\hline 4 & 1953.98 & $\mathrm{C}=\mathrm{C}$ & Aromatics \\
\hline 5 & 1830.51 & $\mathrm{C}-\mathrm{H}$ & Aromatics \\
\hline 6 & 1703.2 & $\mathrm{C}=\mathrm{O}$ & Aldehyde, Aromatic, Amides \\
\hline 7 & 1584.52 & $\mathrm{C}=\mathrm{C}$ & Aromatics \\
\hline 8 & 1439.11 & $\mathrm{C}-\mathrm{H}$ & Methyl, Methylene \\
\hline 9 & 1033.88 & $\mathrm{C}-\mathrm{O}$ & Ether \\
\hline 10 & 843.88 & $\mathrm{C}=\mathrm{H}$ & $\begin{array}{l}\text { Aromatic, } \\
\text { m-substituted }\end{array}$ \\
\hline
\end{tabular}

Table 11: 1.0M Aniline (Abelia Chinensis)

\begin{tabular}{llll}
\hline S/NO & Peak $\left(\mathrm{cm}^{-1}\right)$ & Bond & Suspected Functional Group \\
\hline 1 & 3420.84 & $\mathrm{~N}-\mathrm{H}$ & Amines, Amides \\
2 & 3281.02 & $\mathrm{C}-\mathrm{H}$ & Amines, Amides \\
3 & 3128.61 & $\mathrm{~N}-\mathrm{H}$ & Amines, Amides \\
4 & 2931.90 & $\mathrm{C}-\mathrm{H}$ & Methyl, Methylene \\
5 & 2117.13 & $\mathrm{C}-\mathrm{H}$ & Aldehyde, Aromatics Amides \\
6 & 2696.57 & $\mathrm{C}-\mathrm{H}$ & Aldehyde, \\
7 & 1927.92 & $\mathrm{C}=\mathrm{C}$ & Aromatics \\
8 & 1886.44 & $\mathrm{C}=\mathrm{O}$ & Aromatic, amides \\
9 & 1789.04 & $\mathrm{C}=\mathrm{O}$, & Ketones, Oximes \\
10 & 1325.09 & $\mathrm{C}=\mathrm{N}$ & \\
11 & 1043 & $\mathrm{C}=\mathrm{N}$ & Amines \\
& & $\mathrm{C}-\mathrm{O}$ & Ether \\
\hline
\end{tabular}


Table: 12: 1.5M Aniline (Abelia Chinensis)

\begin{tabular}{|c|c|c|c|}
\hline S/NO & Peak cm ${ }^{-1}$ & Bond & Suspected Functional Group \\
\hline 1 & 3419.90 & $\mathrm{~N}-\mathrm{H}$ & Amines, Amides \\
\hline 2 & 2919.93 & $\mathrm{C}-\mathrm{H}$ & Methyl, Methylene \\
\hline 3 & 1825.68 & $\mathrm{C}-\mathrm{H}$ & Aroamtics \\
\hline 4 & 1728.30 & $\mathrm{C}=\mathrm{O}$ & Aldehyde, Aromatics Amides \\
\hline 5 & 1633.75 & $\begin{array}{c}\mathrm{C}=\mathrm{N}, \\
\mathrm{N}-\mathrm{H}\end{array}$ & Oximes, Amines, Amides \\
\hline 6 & 1510.35 & $\mathrm{C}=\mathrm{C}$ & Aromatic Ring \\
\hline 7 & 1443.77 & $\mathrm{C}-\mathrm{H}$ & Methyl, Methylene \\
\hline 8 & 1032.92 & $\mathrm{C}-\mathrm{O}$ & Ether \\
\hline 9 & 759.10 & $\mathrm{C}=\mathrm{C}$ & Aromatic m-substituted \\
\hline
\end{tabular}

(Silverstein et al. 1974, p. 84-85; Morrison and Boyd 1997, p. 597; Solomon and Fryhle 2007, p. 79-83)

Tables 7-12 shows the absorption bands for immobilized sawdust targeted for the amines. The $\mathrm{N}-\mathrm{H}$ stretching for amines between $3348.64 \mathrm{~cm}^{-1}-3420 \mathrm{~cm}^{-1}$ is due to hydrogen bonding. The $\mathrm{C}=\mathrm{O}$ stretching of amides occurs at longer wavelength than normal is because of its resonance effect. The $\mathrm{C}=\mathrm{O}$ bond for secondary amide occurs while aromatic amides exist due to the competition between the ring and the $\mathrm{C}=\mathrm{O}$ for nonbonding electron pair of nitrogen. The $\mathrm{C}-\mathrm{N}$ and $\mathrm{C}-\mathrm{H}$ stretching of the amides was also indicated. These absorptions showed that the amines reacted with the oxidized sawdust and agrees with the earlier work of Dash et al. (2012 p. 2069).

The sorghum on control (unoxidised) sawdust (plate 1) started germinating after 3 days. The sprouting sorghum appeared healthy after 2 weeks of germination. Thereafter, there was decreased

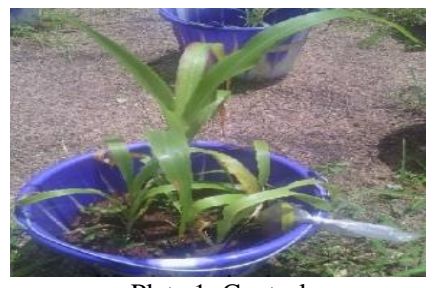

Plate 1: Control

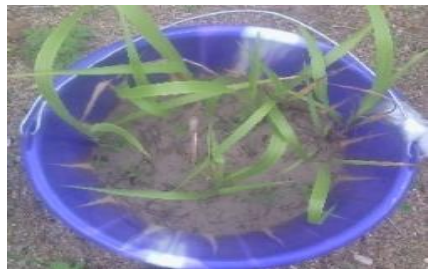

Plate 3: $0.5 \mathrm{moldm}^{-3}$ Aniline Plate

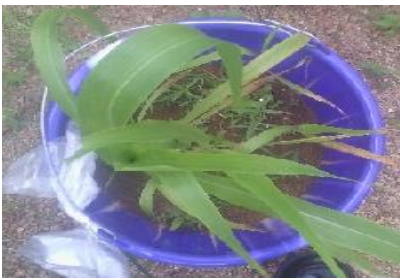

Plate 5: $1.0 \mathrm{moldm}^{-3}$ Aniline Plate growth and yellowish leaves; this is because of nutrients deficiency, infestation and soil acidic ( $\mathrm{pH}$ 5.2) which made it susceptible to leaching of essential nutrients and striga propagation (Dashak \& Shambe 2005, p. 4851).

First application of modified (immobilized) Sawdust on Sorghum was done after 3 weeks and thereafter 2 weeks of germination on all the labeled samples base on the concentrations of dimethylamine and aniline. After the first application, there was no significant improvement in the growth of sorghum due to the effect of immobilization. Nevertheless, on second and third application, there was drastic improvement and absent of weeds. Based on the concentration of the nitrogenous bases, dimethylamine immobilized sawdust on sorghum grows progressively with concentration and absence of weeds, however, aniline immobilized sawdust on sorghum grows progressively higher on 0.5 and $1.0 \mathrm{~mol} / \mathrm{dm}^{3}$ than dimethylamine and decrease in $1.5 \mathrm{~mol} / \mathrm{dm}^{3}$ compared to dimethylamine (plates 2-8). This could be connected to the delocalized nature of aromatic compounds (aniline) and the localized nature of aliphatic compounds (dimethylamine). The ease of release of the aniline compared to dimethylamine inflamed sorghum at higher concentration. Eventhough pretreated lignocelluloses materials; both dry and wet are more hydrophobic than raw counter parts (Acharjee et al. 2011 p. 4849, Adel et al. 2010 p. 4446, Guo et al. 2009 p. 80).

These results shows that soil type, particle sizes, concentration in relation to structure are good factors to considered while controlling striga weed as well as to restore soil fertility.

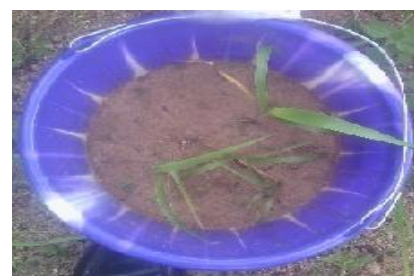

Plate 2: $0.5 \mathrm{moldm}^{-3}$ dimethylamine

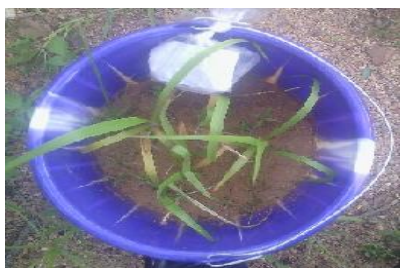

4: $1.0 \mathrm{moldm}^{-3}$ Dimethylamine

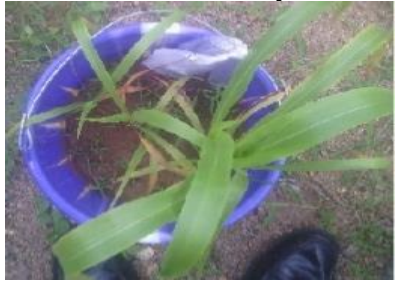

6: $1.5 \mathrm{moldm}^{-3}$ Dimethylamine Plate

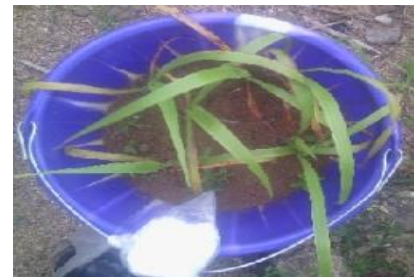

7: 1.5 moldm ${ }^{-3}$ Aniline

\section{Conclusion}

Apart from the already familiar uses of sawdust, chemical modification of sawdust can be use to face the global challenges of food insecurity cause by soil infertility and the effect of parasitic striga in sorghum. Immobilized sawdust should be applied early enough before planting so as to prevent the increase of soil $\mathrm{pH}$ which discourages the growth of striga. The required nutrients should be made available to sprouting sorghum since the decomposition is slow when compared to inorganic fertilizers. The application of modified amines also helps in controlling nutrients leaching and 
runoff water since it has high water absorption capacity. Higher concentration of nitrogenous bases in immobilized sawdust is encouraging in localized than delocalized electron compounds in controlling weed growth and soil acidity. Since nitrogen is abundance in the atmosphere, scientific investigation should be carried out in order to incorporate the nitrogen into the sawdust rather than expending on costly nitrogenous bases.

\section{References}

[1] Acharjee TC, Coronella CJ \& Vasquez VR (2011) Effect of thermal pretreatment on equilibrium moisture content of lignocellulosic biomass. Bioresource Technology 102(7), 4849-4854. https://doi.org/10.1016/j.biortech.2011.01.018.

[2] Adel AM, AbdEl-Wahab ZH, Ibrahim AA \& Al-Shemy MT (2010) Characterization of micro-crystalline cellulose prepared from lignocellulosic materials. Part I. Acid catalyzed hydrolysis. Bioresource Technology 101(12), 4445-4455. https://doi.org/10.1016/j.biortech.2010.01.047.

[3] Adhikary KB. Pang S \& Staiger MP (2008) Dimensional stability and mechanical behaviour of wood-plastic composites based on recycled and virgin high-density polyethylene (HDPE) composites part B. Journal of Composite Materials 39(5), 807-815.

[4] Ayeni AO, Omoleye JA, Hymore FK \& Pandey RA (2016) Effective alkaline peroxide oxidation pretreatment of shea treesawdust for the production of biofuels: Kinectics of delignification and enzymatic conversion to sugar and subsequent production of ethanol by fermentation using saccharomyces cerevisiae. Brazilian Journal of Chemical Engineering 33(1), 32-45. https://doi.org/10.1590/0104-6632.20160331s20140258.

[5] Azam MG, Zoebisch MA \& Wickramarachchi KS (2008) Effects of cropping systems on selected soil structural properties and crops yields in the Lamphraphloeng watershed-northeast.Thailand Journal of Agronomy 7(1), 56-62. https://doi.org/10.3923/ja.2008.56.62.

[6] Badu-Apraku B, Akinwale RO \& Fakorede MAB (2010) Selection of early maturing maize inbred lines for hybrid production using multiple traits under striga-infected and strige free environments.Maydica 55, 261-274.

[7] Bolien W B (2003) Mulches and Soil Conditioners: Carbon and Nitrogen in Farm and Forest Products. Agricultural and Food Chemistry 1(5), 379. https://doi.org/10.1021/jf60005a004.

[8] Clemons C (2002) Wood-plastic composites in the United States: the interfacing of two industries. Forest Production Journal 52(6), $10-18$.

[9] Dash R, Elder T \& Ragauskas AJ (2012) Grafting of model primary amine compounds to cellulose nanowhiskers through periodate oxidation. Cellulose 19(6), 2069. https://doi.org/10.1007/s10570-0129769-2.

[10] Dashak DA and Shambe T (2005) Chemical composition of Striga hermonthica Affected and Unaffected Maize Plant.Journal of Applied Sciences 8(2), 4850-4859.

[11] Demirbas A (2004) Combustion characteristics of different biomass fuels. Progress in Energy and Combustion Science 30(2), 219-230 https://doi.org/10.1016/j.pecs.2003.10.004

[12] Ejeta G (2007) Breeding for striga resistance in sorghum Exploitation of an intricate host parasite biology. Crop Science 47, 216-217. https://doi.org/10.2135/cropsci2007.04.0011IPBS.

[13] Emechebe AM, Ellis-Jones J, Schulz S, Chikoye D, Douthwaite B, Kureh I, Tarawali G, Hussaini AM, Kormawa P \& Sanni A (2004) Farmer perception of striga problem and its control in Northern $\mathrm{Ni}$ geria. Experimental Agriculture 40, 215-232. https://doi.org/10.1017/S0014479703001601.

[14] Guo G, Hsu D, Chen W, Chen W \& Hwang W (2009) Characterization of enzymatic saccharification for acid-pretreated lignocellulosic materials with different lignin composition. Enzyme and Mi$\begin{array}{lll}\text { crobial Technology } & 45(2), & 80-87\end{array}$ https://doi.org/10.1016/j.enzmictec.2009.05.012.

[15] Gurney AL, Slate J, Press MC \& Scholes JD (2006) A novel form of resistance in rice to the angiosperm parasite striga hermonthica. New Phytologist 168(1), 199-208. https://doi.org/10.1111/j.14698137.2005.01560.x.

[16] Harborne JB (1991). Phytochemical methods, a guide to modern technique of plant analysis. 2nd Ed. Chapman and Hall, London. pp. 264.

[17] Haussmann BIG, Hess DE, Welz HG \& Geiger HH (2000) Improved methodologies for breeding striga-resistant sorghums. Field Crops Research 66(3), 195-211. https://doi.org/10.1016/S03784290(00)00076-9.
[18] Haussmann BIG, Hess DE, Omanya GO, Reddy BVS, Welz HG \& Geiger HH (2001a) Major and minor genes for stimulation of striga hermonthica seed germination in sorghum, interaction with different striga population. Crop Science 41, 1507-1512. https://doi.org/10.2135/cropsci2001.4151507x.

[19] Kamara AY, Ellis-Jones J, Amaza P, Omoigui LO, Helsen J, Dugje IY, Kamai N, Menkir A \&White RW (2008) A participatory approach to increasing productivity of maize through striga hermonthica control in Northeast Nigeria. Experimental Agriculture 44, 349-364. https://doi.org/10.1017/S0014479708006418.

[20] Lagoke STO, Parkinson V \& Agunbiade RM (1991) parasitic weeds and their control methods in Africa. In combating striga in Africa (Kim SK ed.) IITA, Ibadan Nigeria, pp. 3-14.

[21] Lal R, (1998) Soil quality and agricultural sustainability. In Advances in Soil Science. CRC Press, Boca Raton, Florida. 17-30.

[22] McNamee P, Darvell LI, Jones JM \& Williams A (2015) the combustion characteristics of high-heating-rate chars from untreated and torrefied biomass fuels. Biomass and bioenergy 82, 63-72. https://doi.org/10.1016/j.biombioe.2015.05.016.

[23] Menkir A \& Kling JG (2007) Response to recurrent selection for resistance striga hermonthica (Del.) Benth in a tropical maize population. Crop Science 47, 674-684. https://doi.org/10.2135/cropsci2006.07.0494.

[24] Morrison RT \& Boyd RN (1997) Organic Chemistry $6^{\text {th }}$ edn. Prentice-Hall India, pp 592-597, 845 .

[25] Moyin-Jesu EI (2007) Use of plant residues for improving soil fertility, pod nutrients, root growth and pod weight of okra (Abelmoschus esculentum. Bioresource Technology 98(11), 2057- 2064. https://doi.org/10.1016/j.biortech.2006.03.007.

[26] Musselman LJ (1987) Taxonomic of witch weeds. In Parasitic weeds in agriculture. CRC Press, Boca Raton, Florida. pp 3-12.

[27] Nassauer S (2011) "Why Wood Pulp Makes Ice Cream Creamier": New injectable and degradable dextran-based hydrogels. The Wall Street Journal 46, 9604-9614.

[28] Perry L (2015) $\mathrm{pH}$ for the Garden. Available at: www.pss.uvm.edu/ppp/pubs/oh34.htm. Accessed ugust 30, 2017.

[29] Rowell RM (2012) Handbook of wood chemistry and wood composites. 2nd ed. CRC Press, Boca Raton, Florida. pp, 39-47. https://doi.org/10.1201/b12487.

[30] Satish K, Gutema Z, Grenier C, Rich PJ \& Ejeta G (2012) Molecular tagging and validation of micro-satellite markers linked to the low germination stimulant gene (lgs) for striga resistance in sorghum [ sorghum bicolor (L.) moench]. Theoritical Applied Genetics 124(6), 989-1003. https://doi.org/10.1007/s00122-011-1763-9.

[31] Sauerborn DDJ (1994) Impact of drought stress and temperature on Striga hermonthica and Alectra vogelii at early growth stage. Ex$\begin{array}{llll}\text { perimental } & \text { Agriculture } & 30, & 249-257 .\end{array}$ https://doi.org/10.1017/S0014479700024182.

[32] Shambe T \& Tersoo O (1993). Immobilization of urea with oxidized and unutilized lignocelluloses materials. Carbohydrates 23, 129-132. https://doi.org/10.1016/0144-8617(94)90037-X.

[33] Silverstein RM, Bassler GC \& Morrill TC (1974) Spectrometric identification of organic compounds. John Wiley \& son, Canada, pp. 84-85.

[34] Solomon TWG \& Fryhle CB (2007) Organic Chemistry $9^{\text {th }}$ edn. John Wiley \& son, India, pp.79- 83.

[35] Yu JC, Peter R, Ma X (2010). The preparation and properties of dialdehyde starch and thermoplastic dialdehyde starch. Carbohy$\begin{array}{llll}\text { drate } & \text { Polymers } & 79 & \text { (2), }\end{array}$ https://doi.org/10.1016/j.carbpol.2009.08.005. 